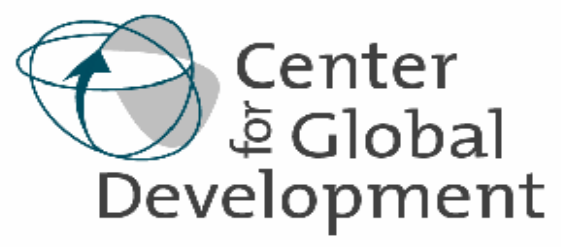

Working Paper Number 63

Jully 2005

Agriculture and Pro-Poor Growth: An Asian

Perspective

By C. Peter Timmer

Abstract
No country has been able to sustain a rapid transition out of poverty without raising
productivity in its agricultural sector. Despite this historical role of agriculture in
economic development, both the academic and donor communities lost interest in the
sector, starting in the mid-1980s. This was mostly because of low prices in world
markets for basic agricultural commodities, caused largely by the success of the Green
Revolution in Asia. After two decades of neglect, interest in agriculture is returning.
This paper explores the reasons why agriculture is back on the policy agenda for donors
and poor countries alike. The most important reason is new understanding that economic
growth is the main vehicle for reducing poverty and that growth in the agricultural sector
plays a major role in that overall growth as well as in connecting the poor to growth.
There is a sharp debate, however, between “optimists" and "pessimists" over the potential
for small-scale agriculture to continue to play these historic roles. In a world of open
trade, ready availability of cheap food in world markets, continued agricultural protection
in rich countries, and economies of scale in access to food supply chains that are
increasingly dominated by supermarkets and export buyers, large-scale farms with state-
of-the-art technology and access to efficient infrastructure can push smallholders out of
commercial markets. Consequently, the paper concludes, geographic coverage and
operational efficiency of rural infrastructure, coupled to effective investment in modern
agricultural research and extension, will determine the future role for agriculture in
poverty reduction.




\title{
Agriculture and Pro-Poor Growth: An Asian Perspective
}

\author{
C. Peter Timmer \\ Center for Global Development \\ Washington, DC
}

Page

Why Agriculture is Back on the Agenda 4

Agriculture and poverty reduction 4

Rural diversification as the conceptual framework 5

The Role of Agriculture in Economic Development 7

Direct contributions (Lewis linkages) 8

Indirect contributions (Johnston-Mellor linkages) 9

Roundabout contributions $\quad 9$

Connecting Agriculture to Poverty Reduction: the Asian Experience 11

The four country studies, plus China 11

The role of the structural transformation 13

The importance of the rural, non-farm economy 16

Connecting Agriculture to Poverty Reduction: General Lessons 17

Valuing the poverty-reducing role of agriculture 18

Getting Agriculture Moving: What worked? 19

The basics of agricultural development 20

Research and technology 20

From agriculture to rural development 22

What role for rural finance? $\quad 22$

Why is this so Hard (Now)? 23

"New" initial conditions 24

Opposition from rich countries $\quad 25$

Stagnant technology and much more complicated problems $\quad 26$

$\begin{array}{ll}\text { Distracted donors and development faddism } & 27\end{array}$

What Should Donors Do? $\quad 29$

$\begin{array}{ll}\text { The obvious steps } & 29\end{array}$

The "optimists" versus the "pessimists" 30

References 32 


\section{Agriculture and Pro-Poor Growth: An Asian Perspective}

\section{Peter Timmer ${ }^{1}$}

Imagine a region of the world where all food and agricultural products were sourced from international markets, and domestic agricultural sectors disappeared. This "world without agriculture" is not imaginary. For many of the world's poorest countries, especially in Africa, a future without agriculture is increasingly being urged as the efficient path to development. Mark Rosenzweig, the new Director of Harvard's Center for International Development, asks at the broadest level "Should Africa do any agriculture at all?” (Harvard Magazine, 2004, p. 57). Adrian Wood, Chief Economist for DfID, envisions a "hollowed out" Africa, with most of the population on the coasts where they could more effectively produce manufactured exports (Wood, 2002). Many macro economists, convinced of the power of rapid economic growth to lift populations out of poverty, see resources devoted to slow-growing agriculture as wasted. In a world of ample food supplies in world markets (some of it free as food aid) and increasingly open borders for trade, what is the role of agriculture in pro-poor growth?

Historically, the answer is clear. No country has been able to sustain a rapid transition out of poverty without raising productivity in its agricultural sector (if it had one to start-Singapore and Hong Kong are exceptions). The process involves a successful structural transformation where agriculture, through higher productivity, provides food, labor, and even savings to the process of urbanization and industrialization. A dynamic agriculture raises labor productivity in the rural economy, pulls up wages, and gradually eliminates the worst dimensions of absolute poverty. Somewhat paradoxically, the process also leads to a decline in the relative importance of agriculture to the overall economy, as the industrial and service sectors grow even more rapidly, partly through stimulus from a modernizing agriculture and migration of rural workers to urban jobs.

Despite this historical role of agriculture in economic development, both the academic and donor communities lost interest in the sector, starting in the mid-1980s, mostly because of low prices in world markets for basic agricultural commodities. Low prices, while a boon to poor consumers and a major reason why agricultural growth specifically, and economic growth more generally, was so poor for the general population, made it hard to justify policy support for the agricultural sector or new funding for agricultural projects (World Bank, 2004d). Historical lessons are a frail reed in the face of market realities and general equilibrium models that show a sharply declining role for agriculture in economic growth.

\footnotetext{
${ }^{1}$ The author is Senior Fellow at the Center for Global Development, Washington, DC. This review essay relies heavily on my own experience over the past several decades, and is a personal interpretation of Asian lessons in relation to the general literature. For alternative treatments of these issues, with a number of similar conclusions, see Dorward, et al. (2004), and DfID (2004). The DfID review in particular, done in collaboration with Anne Thomson of Oxford Policy Management, has a very similar structure and set of arguments as this paper (although the first drafts of the two papers seem to have been done in parallel).
} 


\section{Why Agriculture is Back on the Agenda}

Three factors are renewing interest in agriculture. The first new factor is a revolution in knowledge of basic genetic structures and mechanisms. One result of this knowledge is the development of agricultural biotechnology, but even without genetically modified organisms (GMOs), the genetic revolution will push out the frontier of agricultural productivity dramatically (Naylor and Manning, 2005; FAO, 2004; Timmer, 2003; Mew et al., 2003). Many of these productivity gains can be in developing countries, where they are needed most. In particular, there is a real opportunity to increase productivity of many neglected and secondary crops that have been by-passed by mainstream agricultural research, concerned as it is with improving productivity in the main food staples, rice, wheat and corn. These "orphan” crops, such as millets, sorghums, cassava and other root crops, provide the main sustenance for millions of poor households, especially in Africa (Naylor, Falcon, et.al., 2004)

Second, even in poorer developing countries a supermarket revolution is transforming food retail markets, and the supply chains that provision them, at a faster pace than anyone imagined at the turn of the millennium (Reardon et al., 2003; Hu et al., 2004; Reardon and Timmer, forthcoming). There are important new opportunities for farmers in these countries to diversify out of low-value crops into new commodities with greater demand potential, and thus to capture some of the value added being generated by supermarkets. The strict quality, safety, hygiene, and labor standards demanded by supermarkets are a severe challenge to participation by small farmers and there is concern that rural poverty might worsen as supermarkets expand, but connecting farmers more directly to changing consumer demand offers real hope as well.

Finally, understanding of the determinants of poverty and the mechanisms for reducing it in a sustainable fashion have also undergone a quiet revolution in the past decade. Part of this understanding is recognition that economic growth is the main vehicle for reducing poverty, but for this to work the distribution of income must not deteriorate too sharply. In many circumstances, growth in the agricultural sector has been an important ingredient in the formula that connects economic growth to the poor (Ravallion and Huppi, 1991; Ravallion and Datt, 1996; Ravallion and Chen, 2004; Sumarto and Suryahadi, 2003; Fan, Zhang and Zhang, 2004; Fan, Thorat and Rao, 2004; Timmer, 1997, 2004a, 2005a).

\section{Agriculture and poverty reduction}

Earlier literature stressed the direct impact on poverty reduction that comes from rising rural wages and incomes. Most of the world's poor live in rural areas, or migrated from them in search of better opportunities. It seems almost obvious that growth in agricultural productivity is the surest way to end poverty. The historical evidence confirms this logic. Growth in agricultural productivity not only can increase farm incomes, it also stimulates linkages to the non-farm rural economy, causing economic growth and rapid poverty reduction, with overall growth multipliers almost always significantly greater than one (Hazell and Haggblade, 1993). 
Nonfarm linkages generated by technical change in agriculture can enhance both growth and its poverty-reducing effect. A growing agricultural sector demands nonfarm production inputs, and supplies raw materials to transport, processing, and marketing firms. Likewise, increases in farm incomes lead to greater demand for consumer goods and services. Besides stimulating national economic growth, these production and consumption linkages affect poverty and spatial growth patterns, particularly when agricultural growth is concentrated on small and medium-size farms (Johnston and Kilby, 1975; Mellor, 1976; and Mellor and Johnston, 1984). [Hazell and Haggblade, 1993, p. 190]

But with more open trade possibilities, low prices for staple cereals in world markets, and population growth slowing, the size and relevance of these linkages are no longer so clear. Agriculture must be dynamic and profitable if it is to help reduce rural poverty, and growing staple cereals has not been a source of dynamism in rural economies for two decades. A profitable agriculture with rising productivity will now depend on diversification into crops and livestock with better demand prospects than for cereals, and into production for the agri-business sector, which can add value through processing and enhanced consumer appeal.

\section{Rural diversification as the conceptual framework}

A sequence of progressively broader diversification steps defines a successful agricultural transformation (Timmer, 1988). In countries where farm sizes are small and likely to remain that way for decades because of population pressures and insecure property rights, diversification from production of staple grains to higher-valued commodities will be the first step in this process. The next step will be to move beyond basic commodity production in order to access value-added supply chains for the modern retail sector, especially supermarkets, where the value-added comes in the form of quality, timeliness, food safety, and labor standards in production. These are highly management-intensive factors and may well contribute to economies of scale in production that are not seen in commodity production alone (Timmer, 2004b; Reardon and Timmer, forthcoming).

The next step is the diversification of the rural economy itself, from being primarily driven by its agricultural base to depending more on industrial and service sectors as the base for rural economic growth. This step seem feasible only when population densities permit substantial clusters of activities that feed on themselves for inputs and demand for output (Hayami and Kawagoe, 1993; Lanjouw and Lanjouw, 2001). Thus the effectiveness of the model proposed by Mellor $(1976,2000)$ of demand for laborintensive, rural non-tradables as the vehicle for pro-poor growth, driven by agricultural profitability and wages from labor-intensive exports, would seem to be conditional on good rural infrastructure and human capital, and hence seems to be limited to Asia, parts of coastal and highland Africa, and several countries in Latin America and the Caribbean. At the same time, good rural infrastructure reduces the relative importance of nontradables in local economies and increases competitive pressures from world markets. It is precisely this tension that raises doubts about the future potential for agriculture to be an important driver in poverty reduction, even in rural areas (DfID, 2004). 
Where rural diversification is not economically feasible, the alternative to diversification out of agricultural commodity production will be the transition of economic activity from rural to urban areas. In this transition, the importance of migration (and remittances) will be critical. It is really quite astonishing how little attention is paid to facilitating the migration of rural workers to urban jobs when investments in the rural economy have low payoffs. $^{2}$ One of the main justifications for investing in rural schools and public health facilities is to improve the competitiveness of rural migrants to urban areas.

Whatever the stage or dimension of rural diversification, it must be driven by market demand. Since the 1970s, the development profession has identified "market demand" with border prices and international trade, on the assumption that domestic markets are saturated, politically manipulated, or not remunerative for producers of higher quality products. This focus on international trade has allowed a revolution in food marketing in developing countries to go virtually unnoticed until several years ago, the extensive consolidation of the food retail sector and the rapid rise of supermarkets. The revolution has already created a challenge to higher rural incomes because the process has a tendency to have such high standards for quality, safety, hygiene and farm labor practices that many of a country's own farmers are excluded from the supply chains that provision their consumers, even poor consumers (Reardon et al., 2003; Timmer, 2004b).

In the ultimate stage of rural diversification, globalization permits procurement officers to source food supplies from anywhere in the world, so local farmers compete not just against each other for local consumers, they compete against the global market. But farmers increasingly also have access to the global market if they are the low-cost producer meeting global standards. The future of agricultural development will depend on putting productive new technologies in the hands of farmers and creating an open market environment to make the resulting production as profitable to farmers as employment opportunities in other sectors. Where that development is not possible, and there will be many environments where it is not, rural poverty will only be solved by migration to alternative opportunities, usually in urban areas.

Where the strategy does work, diversifying the rural economy will be the key to increasing income opportunities. Placing rural diversification at the center of agricultural and rural development means there are two quite different tasks that need to be managed simultaneously: (a) raising the productivity of staple food crops for those farmers who continue to grow them; and (b) using the low costs of these staple foods as "fuel" for the agricultural diversification effort, including as the wage good for workers and as feed for livestock. In low-income Asia, diversification will depend on continued availability of low-cost rice, especially in rural markets. In Africa and Latin America, having cheap corn, wheat and rice available in rural markets will be important if diversification is to be successful. Low-cost staple foods are also important to the poor directly, because they devote such a large share of their budget to them, and indirectly, because low real wages, made possible by cheap food staples, make labor-intensive activities more profitable.

\footnotetext{
2 The penultimate draft of the World Bank's Directions in Development: Agriculture and Poverty Reduction, barely mentions the topic (World Bank, 2004d)
} 
Making substantial progress on both of these "rural" tasks will be among the most "propoor" things the development community can hope to accomplish between now and the target date for the Millennium Development Goals in 2015.

\section{The Role of Agriculture in Economic Development}

The role of agriculture in economic development is complicated and controversial, despite a long historical literature examining the topic (Johnston and Mellor, 1961; Hayami and Ruttan, 1985; Timmer, 2002). Part of the controversy stems from the structural transformation itself, which is a general equilibrium process not easily understood from within the agricultural sector (Timmer, 1988). Over long historical periods, agriculture's role seems to evolve through four basic stages: the early "Mosher" stage when "getting agriculture moving" is the main policy objective (Mosher, 1966); the "Johnston-Mellor" stage when agriculture contributes to economic growth through a variety of linkages (Johnston and Mellor, 1961); the "T.W. Schultz" stage when rising agricultural incomes still fall behind those in a rapidly growing non-agricultural economy, inducing serious political tensions (Schultz, 1978); and the "D. Gale Johnson" stage where labor and financial markets fully integrate the agricultural economy into the rest of the economy (Johnson, 1997; Gardner, 2002). These stages were first proposed in Timmer (1988) and are developed in the context of more recent experience in the World Bank's latest treatment of the role of agriculture in poverty reduction (World Bank, 2004d). Efforts to "skip" the early stages and jump directly to a modern industrial economy have generally been a disaster.

Another reason for controversy over the role of agriculture stems from the heterogeneity of agricultural endowments and the vastly different cropping systems seen in Latin America, Africa and Asia (not to mention the diversity within these regions). It is unrealistic to expect much of a common role in such diverse settings. When coupled with the enormous differences in stage of development around the world, and hence the vastly different roles that agriculture plays in economies at different levels of economic maturity, it is easy to understand why there is so little common ground in academia or the donor community on the role of agriculture in economic development. Bravo-Ortega and Lederman (2004) document clearly the different contributions of agriculture to national welfare across these various categories.

There does seem to be widespread agreement in the literature on the basic linkages connecting agriculture and overall economic growth that were first articulated to a general economics audience by Lewis (1954) and Johnston-Mellor (1961). At a conceptual level, these linkages have long been part of the core of modern development theory and practice (Timmer, 1988; 2002). Establishing the empirical value of these linkages in different settings has been a cottage industry since the early 1970s (Byerlee, 1973; Mellor and Lele, 1973; King and Byerlee, 1978; Hazell and Roell, 1983; Haggblade, Hammer and Hazell; 1991; Hazell and Haggblade; 1993; Timmer, 1997; 
Delgado, Hopkins and Kelly, 1998; Fan, Hazell and Thorat, 2000; Fan, Zhang and Zhang, 2002; Fan, Thorat and Rao, 2004).

Virtually all of these studies conclude that the "agriculture multiplier" is significantly greater than one, especially in relatively closed, "non-tradable" economies of the sort found in rural Africa, where the multiplier is often between 2 and 3. But even in the more open economies of Asia, where rice was more tradable than most African staple foods and local prices more easily reflected border prices, the agriculture multiplier is close to 2 in the early stages of agricultural modernization when productivity gains are the fastest. Because economic growth usually has a direct impact on poverty, any contribution agriculture makes to speeding overall economic growth through these large multipliers will, in most circumstances, also directly contribute to reducing poverty (Dollar and Kraay, 2002; World Bank, 2004a).

Despite the potential impact of these large multipliers, a combination of market failures and political biases led to a systematic undervaluation of output from rural economies. Correcting these biases can have economy-wide benefits. The historic bias against the rural sector in developing countries left them starved for resources and discriminated against by macro economic and trade policies (Lipton, 1977; Timmer, 1993). Failures in rural credit and labor markets - some of which can cause "poverty traps" - have provided the analytical context for much of modern neoclassical development economics (Dasgupta, 1993). But even global commodity markets for many products from developing countries "fail" in the sense that agricultural surpluses from rich countries are dumped there, depressing world market prices below long-run costs of production.

A final set of linkages makes growth originating in the agricultural sector tend to be more "pro-poor" than it would be if the source of growth came from the industrial or service sectors (Mellor, 1976; Ravallion and Datt, 1996; Ravallion and Chen, 2004; Timmer, 1997, 2002). New agricultural technologies that improve farm productivity strengthen this connection. Separate reviews by Thirtle, et al. (2004) and by Majid (2004) confirm the strong empirical link between higher agricultural productivity and poverty reduction.

\section{Direct contribution to economic growth via Lewis linkages}

The "Lewis Linkages" between agriculture and economic growth provide the nonagricultural sector with labor and capital freed up by higher productivity in the agricultural sector. These linkages work primarily through factor markets, but there is no suggestion that these markets work perfectly in the dualistic setting analyzed by Lewis (1954). Chenery and Syrquin (1975) argue that a major source of economic growth is the transfer of low-productivity labor from the rural to the urban sector. If labor markets worked perfectly, there would be few productivity gains from this structural transfer. 


\section{Indirect contributions to economic growth via Johnston-Mellor linkages}

The “Johnston-Mellor Linkages” allow market-mediated, input-output interactions between the two sectors so that agriculture can contribute to economic development. These linkages are based on the agricultural sector supplying raw materials to industry, food for industrial workers, markets for industrial output, and the exports to earn foreign exchange needed to import capital goods (Johnston and Mellor, 1961). Again, for the Johnston-Mellor linkages as with the Lewis linkages, it is difficult to see any significance for policy or economic growth unless some of the markets that serve these linkages are operating imperfectly (or, as with many risk markets, are missing altogether). That is, resource allocations must be out of equilibrium and face constraints and bottlenecks not immediately reflected in market prices if increases in agricultural output are to stimulate the rest of the economy at a rate that causes the "contribution" from agriculture to be greater than the market value of the output, i.e. the agricultural income multiplier is greater than one (Timmer, 1995).

\section{Roundabout contributions from agriculture to economic growth}

Writing in the mid-1960s, Mosher was able to assume that "getting agriculture moving" would have a high priority in national plans because of its "obvious" importance in feeding people and providing a spur to industrialization (Mosher, 1966). That assumption has held only in parts of East and Southeast Asia, and has been badly off the mark in much of Africa and Latin America. In the latter regions, a historically prolonged and deep urban bias led to a distorted pattern of investment. Too much public and private capital was invested in urban areas and too little in rural areas. Too much capital was held as liquid and non-productive investments that rural households use to manage risk. Too little capital was invested in raising rural productivity.

Such distortions have resulted in strikingly different marginal productivities of capital in urban and rural areas. New growth strategies--such as those pursued in Indonesia after 1966, China after 1978, and Vietnam after 1989--altered investment priorities in favor of rural growth and benefited from this disequilibrium in rates of return, at least initially. For example, in Indonesia from the mid-1960s to the mid-1990s, farm GDP per capita increased by nearly half, whereas it had declined from 1900 to the mid-1960s. In China, the increase from 1978 to 1994 was nearly 70 percent, whereas this measure had dropped by 20 percent between 1935 and 1978 (Prasada Rao, Maddison and Lee, 2002). A switch in investment strategy and improved rates of return on capital increase factor productivity (and farm income) because efficiency in resource allocation is improved.

One explanation for more rapid and pro-poor economic growth as urban bias is reduced is provided by Mellor's model of agricultural growth, rural employment and poverty reduction that emphasizes the role of the rural non-tradables sector in pulling underemployed workers out of agriculture and into the non-agricultural rural economy. The Mellor model explicitly integrates manufactured export performance (the source of much dynamism in East Asia's economies since the 1960s) and the non-tradables sector in the rural economy (which includes a wide array of local agro-processing) to explain 
subsequent reductions in poverty. This model, drawing on Mellor's earlier work in India (Mellor, 1976) and more recently in Egypt (Mellor, 2000), explains why countries with substantial agricultural sectors that experienced rapid growth from labor-intensive manufactured exports had such good records of overall economic growth and poverty reduction.

An additional set of linkages focuses on more nebulous and hard-to-measure connections between growth in agricultural productivity and growth in the rest of the economy. These linkages grow explicitly out of market failures, and, if they are quantitatively important, government interventions are required for the growth process to proceed as rapidly as possible. The contribution of agricultural growth to productivity growth in the non-agricultural economy stems from several sources: greater efficiency in decision making as rural enterprises claim a larger share of output and higher productivity of industrial capital as urban bias is reduced; higher productivity of labor as nutritional standards are improved; and a link between agricultural profitability (as distinct from agricultural productivity) and household investments in rural human capital, which raises labor productivity as well as facilitates rural-urban migration.

Several of these mechanisms stand out as likely to be important (and potentially measurable) because they draw on the efficiency of decision making in rural households, the low opportunity cost of their labor resources, the opportunity for farm investment without financial intermediaries, and the potential to earn high rates of return on public investments that correct for urban bias. Each of these factors alone, as public investments and favorable policy stimulate growth in the agricultural sector, should cause an increase in the efficiency of resource allocation. In combination, these mechanisms should translate faster agricultural growth into measurably faster economic growth in aggregate, after controlling for the direct contribution of the agricultural sector to growth in GDP itself.

One of the most visible determinants of poverty is hunger and malnutrition. The development profession continues to argue over the causation-whether hunger causes poverty or vice versa--but hunger as a measure of poverty is widely established. Most poverty lines have an explicit or implicit food component. The evidence for nutritional poverty traps, where workers are too malnourished to work hard enough to feed themselves and their families, has strong historical roots (Fogel, 1991, 1994; Bliss and Stern, 1978; Strauss, 1986; Strauss and Thomas, 1998). But simple energy shortages cannot account for very much of the chronic poverty observed over the past several decades because the cost of raw calories, in the form of staple foods, has fallen too sharply relative to wages for unskilled labor (Johnson, 1997; Fox, 2002). If inadequate food intake is the primary cause of poverty, the solution would be in sight (and food aid could be an important part of the answer). If, however, poverty is the main cause of inadequate food intake, hunger will be much harder to end. In most countries, the domestic agricultural sector is likely to play a key role in ending hunger (and ready availability of food aid may well be part of the problem). 


\section{Connecting Agriculture to Poverty Reduction: The Asian Experience}

"Unity in Diversity," the national motto of Indonesia, aptly describes the Asian experience with agriculture and pro-poor growth. Despite enormous diversity in ecological settings, political histories, and economic policies, several common lessons emerge from a long-run review of Asian experience.

\section{Four country studies, plus other Asian experience}

A close reading of the four Asian country studies for the pro-poor growth project of the World Bank (World Bank, 2004a) suggests three fundamentally different, and mostly inconsistent, stories about the role of agriculture in pro-poor growth. First, the Indian case study by Besley, Burgess and Esteve-Volart (BBEV, 2004) argues on the basis of an enormously rich data set and very sophisticated econometrics that agriculture has played a minimal role at best in India's reduction of poverty. BBEV find that both the secondary and tertiary sectors have contributed more to poverty reduction in the main Indian states than has the primary sector, a result that directly contradicts earlier, and seminal, findings by Ravallion and Datt (1996).

Second, the Bangladesh case study (B. Sen, Mujeri and Shahabuddin, 2004) and Vietnam case study (Bonschab and Klump, 2004) each argue that agriculture played a large and crucial role in poverty reduction, but for highly idiosyncratic reasons based on unique initial conditions and domestic institutions. Agriculture was important to pro-poor growth in both countries, but that role cannot be generalized to other countries. Sen does argue that the general Bangladesh experience with economic growth and poverty reduction is relevant to other countries, including those in Africa, that are starting from extreme poverty and with few institutional resources, but Bangladesh's agricultural experience is unique to the ecological setting of the country.

Finally, the Indonesian case study (Timmer, 2005b) argues that conscious policy stimulus to agriculture was the key to the country's 30-year record of rapid, pro-poor growth (from 1967 to 1997), and that the model of smallholder agricultural development used by Indonesia is quite general. The Indonesian model is explicitly set in the broader historical literature on the role of agriculture and economic development that has been generated by successful countries not burdened with highly skewed land distributions as a starting point for their development (Johnston and Mellor, 1961; Johnston and Kilby, 1975; Hayami and Ruttan, 1985, Timmer, 1988, 2002).

Unfortunately, broadening the perspective to the rest of Asia from just these four country studies, and to the longer historical record, does nothing to reconcile these three disparate interpretations of the role of agriculture in pro-poor growth. The Japanese example, long thought to be the early model of agriculture-led growth in Asia (Ohkawa, 1965, Ohkawa, Johnston and Kaneda, 1969; Ohkawa and Rosovsky, 1976) has been challenged by modern historians using general equilibrium models to analyze sectoral relationships (Brandt, 1993; van der Eng, 1993). The result is that agriculture in post-Meiji Japan 
seems to have been more of a "hand-maiden" than the "engine" of economic growth, to borrow Irving Kravis’s (1970) phrase.

Similarly, no clarification comes from the Korean or Taiwanese examples. Korea has long been held out as the counterexample to an important role for agriculture in economic development (Moon, 1975; Ban, Moon and Perkins, 1980), with state-directed, export-led industrialization as the engine of growth and poverty reduction. Even the Taiwanese example, long cherished by agricultural development specialists as a model for ruralbased poverty reduction (Oshima, 1987; Lee, 1971; Mellor, 1976; Johnston and Kilby, 1975; Ranis and Stewart, 1987), has recently seen a surprising empirical rejection of that role. Warr (2003) can find no significant impact from agricultural growth on poverty reduction in Taiwan between the 1960s and the 1990s, whereas industrial growth was a statistically significant and powerful driver of poverty reduction. This result is surprisingly similar to what BBEV (2004) report for India.

Finally, to add to the confusion, Ravallion and Chen (2004) report that nearly all of the remarkable reduction in poverty in China between 1980 and 2001 was the result of agricultural growth specifically and diversified rural economic growth more broadly. They can find very little impact from growth in urban industrial and service sectors on reductions in the headcount poverty index (or the poverty gap or squared poverty gap).

What are we to make of all this confusion? First, enforcing common data, definitions, and methodologies would help clarify the different cases considerably. For example, the panel data used by BBEV permit them to estimate a fixed-effects model that controls for state and year effects, a procedure not attempted in the other country studies. But much of the impact of agriculture on poverty is likely to be specific to states and years because of ecological endowments and annual variations in the monsoon. Removing these from the statistical discussion may be a "baby with the bathwater" phenomenon. Despite efforts to impose a common methodology on the country studies, it is difficult to compare them with respect to the impact of agriculture on pro-poor growth.

Second, looking beyond "first-round" effects of agricultural growth directly on poverty reduction is crucial, because linkages and multipliers are both conceptually and empirically important in the imperfect market economies under investigation. Again, a common methodology and data structure would help enormously, especially if the careful study carried out by Fan, Thorat and Rao (2004) for India could be replicated for other Asian countries. Their dissection of the poverty impact of various agricultural investments and subsidies, disaggregated by decade from 1950 to 2000, shows clearly the mechanisms by which the multipliers work and, importantly, how their quantitative impact changes over time as the structure of the economy evolves. There is obviously no single answer to the question, "what is the size of the agricultural multiplier?"

Third, the key question is, "what would the Asian poverty record look like if these countries had ignored their agricultural sectors?" An alternative way to ask the question is "what would Asia look like now if it had followed African development strategies for the past three decades?” Posing the counterfactual in this fashion is rather sobering, for it 
suggests that the "agriculture does not matter" results are missing an important part of the historical story. Purging endogeneity from our econometric models and results, and concentrating analysis on only what we can measure with great precision, may also be throwing out much of what is important to the policy choices actually made by governments. The very ambitious analysis by Smith and Urey (2002) of the relationship between agricultural growth and poverty reduction in India since 1950 shows very clearly the important investments and policy attention to reaching India's rural poor through institutional and technical change in agriculture. This attention before the Green Revolution established an environment in which the new technologies could have widespread impact on both the rural and urban poor.

Finally, asking about the role of agriculture in pro-poor growth seems to be asking the question in too narrow a fashion. All four of the country studies, and the Ravallion-Chen study of China, note (sometimes just in passing) that the rural non-farm economy has been (or in the case of Vietnam, could be) an important mechanism for connecting the poor to economic growth. It is here that the linkages among agricultural growth per se, overall economic growth, and the connection of the poor to that growth, become crucial, for most of these linkages are likely to be transmitted via the rural non-farm economy (and via changes in food prices for economies that are not totally open to world markets or which might be "large" actors in those markets, such as the countries in Asia discussed here). The World Bank review of the Bangladesh rural non-farm sector (World Bank, 2004c) has an especially clear framework for understanding these linkages, and measuring their empirical relevance in Bangladesh. A similar review is just starting in Indonesia.

Still, the question for this paper is the role of agriculture in pro-poor growth, and it remains important to understand the answer because most government agencies, programs, statistical accounts, and donor assistance are organized by sector. Scientific research and technical change tends to be crop and animal specific, as the difficulty in improving complex cropping systems demonstrates. And, as will be argued below, it remains likely that the household incomes from a profitable agriculture, plus the market demands for inputs and output marketing and processing generated by these household enterprises, remain the "prime mover" of the overall rural economy until very late in the development process. At this point tourism, industry and high-value services relying on modern communications technology can be located anywhere.

\section{The Role of the Structural Transformation}

Standing back from the wealth of detail available in the country studies and supporting documents listed in the bibliography, an “Asian” pattern of rural development and poverty reduction emerges. The common structure involves the evolution of the agricultural sector from a starting point of household subsistence production, through the adoption of new technologies that provide surpluses and rural food security, to more diversified farm activities driven by commercial forces, and finally to the full integration of the agricultural economy into the overall economy. 
This structural pattern can be examined from two directions: first, from the perspective of the main policy concerns shown by Asian countries at each stage, and the links between these policy concerns and the key economic drivers and mechanisms for change. Asia may have been unique in its early concern for food security, including for rural households, as the main policy focus that mobilized substantial resources on behalf of agriculture (Timmer, 2005a). The importance of rice in Asian food security, and the tenuous (and tense) relationship between domestic rice economies and the world market for rice, focused political and economic attention on agricultural productivity in ways not seen in other parts of the world.

For Asia, the Green Revolution technologies for wheat and rice transformed their potential for a domestic approach to food security. When this potential was fully realized, in Indonesia in the early 1980s, in India in the late 1980s, in Bangladesh in the early 1990s and in Vietnam in the mid-1990s, the policy concern turned to supporting farm incomes in the face of declining world prices for cereals. The "efficient" way to do this was through the next structural phase, into diversification and specialization, and Bangladesh seems to be moving in this direction. The more advanced regions in China are already well down this road. The alternative approach, however, is to maintain farm incomes by protecting the rice sector, using subsidies to keep inputs cheap, and thus to slow the diversification process. Both India and Indonesia are caught in this expensive and distortionary approach. It is impossible to move on to the stage of rapid productivity growth and integration into the overall economy as long as the diversification phase is postponed.

The second perspective on these structural changes is from the point of view of relations between the farm and rural non-farm sectors. None of the country papers spend much time on the rural non-farm sector, although the Indonesia paper stresses the importance of Mellor's model of non-tradables production, mostly in rural areas, as the key to understanding the role of agriculture in pro-poor growth (Timmer, 2005b, pp. 20-22). But the broader literature helps understand this role more clearly. In particular, there seems to be a structural transformation of enterprises in the rural non-farm sector that parallels that of agricultural enterprises, as they evolve from very small household-based enterprises into larger firms with "permanent" structures as the place of business. These permanent, rural non-farm enterprises were the fastest growing part of the Bangladesh economy in the 1990s (World Bank, 2004c).

All of the Asian countries are having a very difficult time transitioning from the "food security" to the "farm income" and on to the "rural productivity" objective for public policy (Timmer, 2005a). The difficulties are clearest in India and Indonesia, where the preferred policy mechanism is price protection and input subsidies, not diversification and commercialization. Similar pressures are evident in Bangladesh, Vietnam and China, but budget pressures and more successful diversification by the market have helped keep the structural retardation under control.

This retardation is seen most clearly in enterprise productivity in the rural non-farm sector. India and Indonesia are seriously lagging in this regard. China, because of its 
unique institutional history and experience with town and village enterprises (TVEs), seems to be in the vanguard of rural enterprise development. Bangladesh, because of sheer population density and shrinking agricultural land, is developing productive rural non-farm enterprises at a surprisingly rapid rate (World Bank, 2004c). There is little information on the topic in the Vietnam paper, but it does suggest that rural non-farm enterprises should become the leading source of rural employment growth in that country. The problem until now has been the socialist planning legacy and restricted property rights for owners of non-farm rural enterprises. Accordingly, Vietnam has focused more on an urban growth pole model than on diversified rural enterprises. As a consequence, rural to urban migration is a much larger factor in the poverty reduction story in Vietnam than it seems to be in the other countries studied.

Much of India's problem stems from the "structure" of its support to the rural economy, i.e. from the relative size of subsidies compared with investments, especially in roads and agricultural research (Fan, Thorat and Rao, 2004; World Bank, 2004b). The political economy of agricultural subsidies in a democracy is well understood, but India is the poorest country to try them on such an extravagant scale. The cost is not just to the budget, although that is high enough. The larger costs seem to be to the agricultural transformation itself, and hence to the structural transformation, which is the only longrun hope for India’s poor.

The other "large" common theme across the papers with respect to the role of agriculture in pro-poor growth is the impact of food prices on poverty. In India, Indonesia, and Bangladesh, the story is consistent and unambiguous. Higher productivity in the food crop sector, especially in domestic rice production, led to lower relative food prices in both rural and urban areas, with very substantial impact on the poor. The India and Bangladesh papers argue that this mechanism may have been the leading contribution of agriculture to pro-poor growth.

The impact of rice prices on the poor in Vietnam is more complex. Much of Vietnam's rapid poverty reduction was driven directly by higher incomes in rice-producing households, stimulated to a large extent by the realignment of the exchange rate and consequently greater price incentives for production and export. In some sense, Vietnam's reforms transformed rice from a non-tradable to a tradable commodity, with large gains in efficiency and output. But regions less well situated for rapid expansion of rice production, and the poor in urban areas, were probably hurt by this new economic environment. Bonschab and Klump (2004) argue that much of the widening in income inequality across regions was because of differential potential for rice exports.

The Chinese story seems to be radically different. Ravallion and Chen (2004) show that poverty rates fall dramatically when rural producer prices are higher, implying that most of the rural poor have their net incomes directly and positively affected by food prices. Because of the nature of the Chinese food marketing system however, Ravallion and Chen argue that improving terms of trade for farmers is equivalent to removing a tax on their incomes and does not actually have a direct impact on food prices for consumers. If 
this is the case, then the Chinese example also follows the more general pattern in Asia where lower food prices directly benefit the poor.

\section{The Importance of the Rural, Non-Farm Economy}

Even when comparing five of the largest countries in the world, all of them rice-based food economies in Asia (with apologies to the wheat farmers in Bangladesh, China and India, and the maize farmers in poorer parts of most of these countries), it is striking how diverse they are, both at one time across countries and within a single country across time. This diversity extends to the role of agriculture in pro-poor growth, in three important ways.

First, the initial conditions and institutional settings for rapid gains in productivity varied enormously in the 1960s, when new rice and wheat technologies became available from the International Agricultural Research Centers (or from domestic centers in China). India had been investing heavily in irrigation, agricultural universities, land reform, and fertilizer production well before the Green Revolution, whereas Indonesia had virtually destroyed what little agricultural infrastructure remained when the Dutch were forced out. Bangladesh took over a decade to become a functioning country after independence in 1971. Vietnam was prone to famines before 1989 and imported rice to feed even its farm population. Opening its economy and stabilizing macro policy led to a surge in agriculture, but continued socialist controls on private ownership and market restrictions prevented a dynamic rural non-farm sector from emerging. Migration has become a leading source of poverty reduction in Vietnam. Despite the early success in China with TVEs, rural to urban migration has also been essential there to linking the poor to economic growth.

Second, despite all the temporal and cross section diversity, a common pattern of structural transformation can be seen. The Asian experience shows clearly that this structural transformation is driven by a successful agricultural transformation. In turn, the investments in agriculture needed for this transformation, in both policy and financial terms, were driven by a deep political concern for food security (Timmer, 2005a). The very integrity of the state was threatened by hunger and famine, whether in democratic India, autocratic Indonesia, or communist Vietnam or China (although the communist countries certainly held out longer in the face of hunger and famine than did the more open societies). This concern for food security drove the transition from subsistence agricultural to rural food surpluses, thus alleviating rural poverty directly, and overall poverty through lower real food prices.

Third, diversity returns again at the next stage. None of these five countries has yet managed a successful transition from rural food security to rural productivity through diversification and commercialization. Some countries are more successful than others, as parts of China, Bangladesh, and areas on Java are responding quickly to the economic signals pushing in this direction. But almost uniformly, policymakers are resisting this transition, apparently because they fear a loss of food security as measured by the relative volume of rice imports. 
A reader from outside Asia, seeking lessons for Latin America or Africa from these five countries, would be excused for being totally confused. Gains in food crop production, stimulated by government investments, subsidies to inputs, and guaranteed output prices, were the initial basis for pro-poor growth in all these countries. But now those same policy instruments are counterproductive both for growth and the poor. Agriculture needs to restructure into a diversified and commercialized sector that will have little direct impact on the poor, even through food prices. At this stage, especially in India and Indonesia, agriculture's main impact on poverty is more likely to come through its support for a dynamic rural non-farm economy, which will be a bridge for the rural poor to cross on their way to jobs in the formal economy.

This role does not show up in the econometric tests of agriculture's contribution to poverty reduction, for two reasons. First, this "new" agriculture is still largely nascent, and hence does not appear in the statistical record very clearly. Second, the impact will be through the linkages and multipliers that have been hard to conceptualize, model and estimate, because they depend so crucially on local conditions and institutional context. That does not mean that the role of agriculture in pro-poor growth has diminished to the point of being irrelevant. It does mean that agriculture's role, as always, must be understood in the context of multi-sectoral and general equilibrium frameworks, not through a sectoral lens alone.

\section{Connecting Agriculture to Poverty Reduction: General Lessons}

In current strategies used by countries and donor agencies to cope with poverty, the role of agriculture has been limited, largely because of failure to recognize the importance of direct links between agricultural development, food availability, caloric intake by the poor, and reduction in poverty. Part of the reduction in poverty is definitional because the poverty line is often measured in caloric terms. But raising caloric intake of the poor has a positive effect on their well-being, work productivity, and investment in human capital. Empirical evidence provided by Paul Schultz (1993) and Fogel (1991) illustrates this importance, but a more general case can also be made.

The case builds on three empirical relationships: between agricultural growth and poverty alleviation; between increases in domestic food production and improvements in nutrient intake; and between agricultural productivity and productivity growth in the rest of the economy. It has long been established that, for a given level of income per capita, a higher share of GDP originating in agriculture contributes to a more equal distribution of income (Kuznets, 1955; Chenery and Syrquin, 1975). An agriculture-driven growth strategy, if it does not sacrifice aggregate growth, directs a greater share of income to the poor, i.e. it is more pro-poor. This is the essential first step in breaking the cycle of poverty. 
Next, increases in domestically produced food supplies contribute directly to increases in average caloric intake per capita, after controlling for changes in income per capita, income distribution, and food prices (Timmer, 1996). Countries with rapidly increasing food production have much better records of poverty alleviation, perhaps because of changes in the local economics of access to food, changes that are not captured by aggregate statistics on incomes and prices. The most recent confirmation of this relationship is in Majid (2004). With the \$1 per day headcount poverty rate from the ILO data set as the dependent variable, both the log of agricultural output per worker and the per capita food production index have a large and statistically significant impact on reducing poverty (controlling for per capita income and other standard variables).

Whatever the mechanisms, intensive campaigns to raise domestic food production through rural investments and rapid technical change, can be expected to have positive spillover effects on nutrient intake among the poor. This is the second step in breaking the cycle of poverty.

The third step is to ensure that these sectoral gains can be sustained without distorting the economy or destroying the environment. These dual goals can be achieved only if factor productivity increases for the entire economy. Eventually, growth in factor productivity must provide a substantial share of total growth in income per capita. When using its resource base efficiently, agriculture has a key role to play at this stage as well (Sarris, 2001; Timmer, 2005c).

\section{Valuing the poverty-reducing role of agriculture}

Agriculture has been seriously undervalued by both the public and private sectors in those societies in which poverty has remained untouched or even deepened. In addition to an urban bias in domestic policies, the root cause of this undervaluation is a set of market failures. Commodity prices, by not valuing reduced hunger or progress against poverty, often do not send signals with appropriate incentives to decision makers. These inappropriate signals cause several problems, in addition to those noted above.

First, low values for agricultural commodities in the marketplace are reflected in low political commitments. But political commitments to rural growth are needed to generate a more balanced political economy, with less urban bias than has been seen in most developing countries historically (Lipton, 1977; Timmer, 1993). The developing world has already seen a notable reduction in the macroeconomic biases against agriculture, such as overvalued currencies, repression of financial systems, and exploitive terms of trade (Westphal and Robinson, 2002). Further progress might be expected as democracy spreads and empowers the rural population in poor countries (although agricultural policies in most democracies make economists cringe).

The second problem with low valuation of agricultural commodities is that rural labor is also undervalued. This weakens the link between urban and rural labor markets, which is often manifested in the form of seasonal migration and remittances. There is no hope

of reducing rural poverty without rising real wages for rural workers. Rising wages have 
a demand and a supply dimension, and migration can affect both in ways that support higher living standards in both parts of the economy. Migration of workers from rural to urban areas raises other issues, of course, but those issues depend fundamentally on whether this migration is driven by the push of rural poverty or the pull of urban jobs (Larson and Mundlak, 1997).

Either way, the food security dimensions of rural-urban migration are clear. Urban markets become relatively more important in supplying food needs for the population. Whether the country's own rural economy or the world market is the best source of this supply will be one of the prime strategic issues facing economic policy makers and negotiators for the Doha Round of trade deliberations (Naylor and Falcon, 1995; Tabor, 2002; Elliott, 2004). It is no accident that China, through its commitments upon entering the WTO, has decided to use world markets to provision a significant share of its basic food supply. The intent is to keep food costs low and stable and thus to provide a competitive advantage to its labor-intensive industries and producers of high-value agricultural commodities. China sees few income opportunities for small-scale producers of staple grains.

\section{Getting Agriculture Moving: What worked?}

There is no great secret to agricultural development. Mosher (1966) and Schultz (1964) had identified the key constraints and strategic elements by the mid-1960s. New agricultural technology and incentive prices in local markets combine to generate profitable farm investments and income streams that simultaneously increase commodity output and lift the rural economy out of poverty (Hayami and Ruttan, 1985). The process can be speeded up by investing in the human capital of rural inhabitants, especially through education, and by assistance in the development of new agricultural technology, especially where modern science is needed to play a key role in providing the genetic foundation for higher yields.

Beyond this level of general understanding, however, the diversity of rural circumstances has complicated agricultural development and made it country-specific. The mechanisms for both technology development and provision of rural price incentives are no longer as clear as they were in the 1960s (DfID, 2004). The Consultative Group for International Agricultural Research (CGIAR), manager of such centers as the International Rice Research Institute (IRRI) in the Philippines, has produced many breakthroughs for the world's staple grains. But core funding for the system has been falling for nearly two decades as the market prices of these crops have dropped to historic lows, under the weight of productivity gains in developing countries and government-subsidized crop surpluses in rich countries. 


\section{The basics of agricultural development}

History does provide general insights into the components of an agricultural development strategy. First, obviously, is a supportive macroeconomic policy, one that yields low inflation, a reasonably stable exchange rate, positive real interest rates, and perhaps some monitoring of disruptive short-run capital flows. Second, "getting prices right" extends good macro policy to the trade arena, where an open economy with low barriers to both internal and external trade should generate a level playing field for producers and consumers alike. The need to keep these barriers low is one of the major arguments against interventionist price policies for staple foods, even when a case can be made on the basis of protecting the poor or stabilizing the economy (Timmer and Dawe, 2005).

Price support and stabilization programs were ubiquitous throughout Asia during the drive to adopt "green revolution" technologies (Timmer, 1991, 2005a; Dorward, et al., 2004). Their continued role is questionable, however, as world rice markets are now just as stable as wheat and maize markets, and the institutional mechanisms used to implement these programs, especially parastatals with monopoly control of grain markets, have become hopelessly corrupt and ineffective (Cummings and Gulati, 2004). Thus the modern judgment is that just two basic components make up the essentials of "good economic governance" that underpin modern economic growth—sound macro economic policy and an open trade policy. ${ }^{3}$ Agricultural development strategies must work within this "neutral" policy framework.

What remains after this? The externalities from rural growth outlined above argue for a significant public role in funding agricultural research and rural infrastructure, including rural schools and public health clinics. A competitive exchange rate will tend to keep rural tradables profitable, but investments to keep marketing competitive, especially through provision of timely market information, and to lower transactions costs in local and regional markets, will enhance this profitability. In most rural environments, irrigation facilities and electrification will have a strong public component. But macro economists note that these investment funds come at high opportunity costs to other sectors, or because of the distortions caused by public taxation, so providing clear benefit-cost justifications for their utilization will be important, and hence the concern for accurately valuing agricultural output.

\section{Research and technology}

No country has successfully transformed its agricultural sector and established strong rural-urban links to economic growth without sharply improving the level of technology used on its farms. From the "agricultural revolution" in $18^{\text {th }}$ century England that fueled the first Industrial Revolution, to the "green revolution" that stimulated Asia's "economic miracle," new crop and livestock technologies have raised yields and generated rapid growth in total factor productivity in rural areas (Timmer, 1969, 2005; Mundlak, 2000). Modern science has increasingly been the source of these crop and livestock

\footnotetext{
${ }^{3}$ The country case studies for "operationalizing pro-poor growth" show how difficult it has been to have a growth-oriented macro policy, especially in the context of Dutch Disease (Cord, 2004).
} 
technologies. As the skills and financial infrastructure needed to develop this science and apply it to agricultural problems outpace their availability in many poor countries, the importance of supporting basic research at international centers--as a global public good-becomes stronger (Pardey and Beintema, 2001).

But equally important is the adaptive research in national research centers that translates the basic agricultural science from the international centers into locally adapted plants and animals (Hayami and Ruttan, 1985). Funding for these national centers has been under pressure for the past two decades, as budgets have more or less followed world commodity prices on their downward track (see Box 1). And completely unanswered at this point is the role bio-technology and genetically modified organisms (GMOs) might play in raising agricultural productivity in poor countries (Naylor and Manning, 2005; FAO, 2004; Timmer, 2003; World Bank, 2004d). Part of this role is likely to be in the development of more productive germplasm for the so-called "orphan crops" that provide the bulk of staple foods for many poor households, especially in Africa and highland areas of Latin America (Naylor, Falcon, et al., 2004).

\section{Box 1: Top scientific journals call for more public funding of rice research}

The leading scientific journals Nature and Science have both published calls urging renewed financial support for the Philippines-based International Rice Research Institute (IRRI).

"Despite rumors to the contrary, the role of the International Rice Research Institute is as important as ever," begins the editorial in the 1 May issue of Nature (Vol. 423) entitled Rice institute needs strong support. However, it adds, "In the three years from 2001 to 2003, IRRI's core funding dropped by $26 \%$, and similar cuts are expected in the future." ...

In the same week, the 2 May issue of Science (Vol. 300) ran a broader look at the Green Revolution and the role played by IRRI and the other 15 international agricultural research centers (IARCS) in the Consultative Group on International Agricultural Research. In summarizing the findings of their book Assessing the impact of the Green Revolution, 1960 to 2000, R. E. Evenson and D. Gollin wrote that "the IARCS will have an important role to play in generating and sustaining future advances in agricultural technology for the developing world."

The Science authors add, "The budgets of many IARCS, not to mention many of their national program counterparts, have declined sharply in real terms over the past decade.” This has come about, the authors surmise, in part because development agencies, "perhaps eager to find shortcuts to development, have tended to shift funding away from agricultural research and toward other priorities."

Press Release from IRRI, May 2003 


\section{From agricultural to rural development}

Once all these elements are in place as the basis for profitable farming, policy attention and budget priorities should turn to the rural non-tradables sector. Part of the profitability for this sector will come from a labor-intensive export sector that is successfully linked into the global economy, and in many countries this will include the agri-business sector. Rapid growth in this export sector creates demand for labor directly as well as for the goods and services of the rural economy that raise demand for labor indirectly.

The rural non-farm sector is usually the bridge between commodity-based agriculturewhich is often on a "treadmill" between rising productivity and falling prices (Gardner, 2002) — and livelihoods earned in the modern industrial and service sectors in urban centers. Throughout Asia most rural households earn half or more of their incomes from non-farm sources, and often this sector is the "ladder" from underemployment at farm tasks to regular wage employment in the local economy, and from there to jobs in the formal sector (Mellor, 2000; Delgado, Hopkins and Kelly, 1998).

\section{What role for rural finance?}

A certain enthusiasm has grown over the past decade for market-based rural finance initiatives that circumvent the problems faced by earlier efforts to provide subsidized credit to small farmers so they could adopt modern technologies (Morduch, 1999). By tapping the knowledge of local villagers of each other's capacities for repayment of loans, grassroots micro finance operations have been widely established to provide vehicles for risk management and household savings. Unfortunately, there is no significant evidence that these operations actually contribute to economic growth. Somewhat more surprising, the evidence is thin that such schemes actually reduce poverty in a sustainable fashion (Zeller and Meyer, 2002).

What does seem to work, but which is much more difficult to implement, is a formal system of rural-urban financial intermediation that improves factor mobility. Linking small, rural, local savings to investment opportunities outside the rural economy is arguably an important way to help households maximize returns on their capital, create incentives to save, and smooth the flow of resources out of agriculture as part of the structural transformation. Establishing these linkages, however, requires reasonably large financial institutions, able to establish branch offices in rural areas and tap modern financial instruments in urban areas. Such institutions tend not to spring up from rural roots. 


\section{Why is this so Hard (Now)?}

Creating a dynamic and efficient agriculture was never easy, but policymakers in the 1960s and 1970s had significant advantages over those in the 1980s and 1990s in creating the right environment for both public and private investments in their rural economies. ${ }^{4}$ The differences fall into four basic categories: (1) "new" and more difficult initial conditions confronting policymakers; (2) rising opposition from rich countries, both in the form of protection of their own farmers and concerns over losing their export markets; (3) a relatively stagnant shelf of available agricultural technologies that could be easily borrowed and widely adopted by farmers; and (4) donors who have been distracted from their core mission by development faddism and pressures from "single-issue" interest groups.

DfID (2004) characterizes the same issues into two camps, the "smallholder optimists" and the "smallholder pessimists." The debate between the two camps is sharp:

There is probably less of a consensus now-particularly amongst development agencies - on the best (in terms of impact on poverty and hunger) agricultural development strategy than at any time over the last half-century or longer (Ashley and Maxwell, 2001). This is particularly true of Africa, where an unsuccessful model based on improving performance through technology supported by publicly owned development agencies has been replaced by the equally disappointing response of farmers to the liberalization of markets (Dfid, 2004, p. 19).

The smallholder pessimists, such as Maxwell (2004), argue that small-scale agriculture is becoming increasingly uncompetitive in the face of the revolution in supply chains and globalization of food trade. The smallholder optimists, on the other hand, led by Lipton (2004) and scholars at IFPRI, hold that the historic relationships between agriculture and economic growth still hold, especially in Africa where smallholders are "protected" by high transportation costs and the cultivation of many non-tradable food commodities. Naturally, the policy conclusions of the two camps are totally different, and depend fundamentally on whether it is possible to skip the stage of agricultural modernization in the structural transformation.

\footnotetext{
${ }^{4}$ A similar interpretation of the problems facing policymakers in developing countries in the 1960s and 1970s, versus the problems facing policymakers now, is in Dorward, Kydd, Morison and Urey (2004). They stress the sharply different attitudes among the donors now toward governmental interventions in support of agricultural development, and are perhaps less concerned about the widespread governmental failures in those efforts. This paper is more concerned about the origins of these donor attitudes in the policies of the rich countries and their concern to protect their own farmers. In the end, we have very similar policy conclusions.
} 


\section{“New” initial conditions}

The initial success of the green revolution, and from it of agriculture as the engine of propoor economic growth, was in East and Southeast Asia. Despite difficult initial conditions in the minds of many-heavy population pressures against available arable land, poorly educated and overwhelmingly rural populations, with widespread and deep poverty - these turned out to be precisely the initial conditions that made investments in new agricultural technology and rural infrastructure highly profitable. The remaining poor countries in Africa and Central Asia face low population densities in their low productivity areas, and hence building rural infrastructure to raise productivity in these areas is prohibitively expensive.

Second, the real prices of agricultural commodities are now very low in historical terms, thus making it difficult to justify investments whose payoff will be increased production of exactly these low-valued commodities. The real price of rice in world markets has dropped from $\$ 1000$ per metric ton to $\$ 200$ per metric ton in the past quarter century, and many other agricultural commodity prices have followed a similar trend (Dawe, 2001, 2002; World Bank, 2004d). With average farm size decreasing in most countries due to population growth, finding a technology package and farm-gate price that will increase farm household incomes above the poverty line is more than five times harder now than in the mid-1970s.

Third, the easy investments in hospitable environments, especially for irrigation infrastructure, have mostly been made. In the same fashion, high-yielding seed technology for widely uniform planting environments has been developed. What remains are the more distant, more difficult, and less productive agricultural settings that have been bypassed by the main stream of the green revolution. To add to the difficulties, the world now has more concern for environmental degradation, whether from expanding cultivated area into tropical rain forests, upstream and downstream impacts from construction of large dams, or simply the impact on fragile ecosystems of highly intensive cropping systems. These environmental concerns have substantially raised the barrier to any large scale investment in raising agricultural output, at least with donor financing.

In combination, the initial conditions facing the currently poorest countries (and regions), precisely those by-passed by the first green revolution, are far more difficult than those facing the successful countries in East and Southeast Asia. The obvious question, but one without an obvious answer, is whether agricultural development is now simply too expensive, or too controversial, to pursue as the engine of pro-poor growth, even for those countries where the vast majority of the poor are farmers. 


\section{Opposition from rich countries}

Increasingly, the rich countries are part of the problem rather than part of the solution. Agricultural protection in the OECD countries remains very high, despite agreements at the Uruguay Round of trade negotiations that brought agriculture within the purview of the WTO. This protection has two pernicious effects. First, by maintaining production levels well above those that would be profitable without the subsidies and protection, global supplies are increased and world prices are lowered. The actual consequences for developing countries are mixed and controversial, as a number of countries protect themselves against these "unfair" prices. It is entirely possible that farmers and consumers in Indonesia, for example, might face lower rice prices after market liberalization because of the high protection provided now.

Second, and perhaps more important, the rich countries have reserved an increasing share of world agricultural consumption for their own protected farmers. The share of rich countries in agricultural exports has actually increased significantly in the past thirty years, contradicting everything economists think they know about comparative advantage and the structural transformation. This would simply not have been possible without the massive subsidies the rich countries devote to their farmers. The impact, of course, is to take market share away from the world's poorest farmers.

There is also a disconcerting concern in the legislatures of some rich countries, and especially in the United States, that successful agricultural development in poor countries will impair the export markets for agricultural products from rich countries. This concern is manifest in legislative directives that prohibit USAID, for example, from helping poor countries develop their soybean, sugar, or orange industries. It is manifest in the continued insistence that food aid is "development assistance," despite overwhelming evidence that food aid usually distorts market incentives for local farmers (Oxfam, 2002). Cash transfers of even half the nominal value of the food aid would almost certainly do more good.

Efforts have been made over the years to build the case that agricultural development is the necessary first step from which overall economic development is built, and that richer countries quickly graduate from being aid recipients to growing commercial markets for agricultural exports. That case has strong historical precedents, and there can be little doubt that national welfare in both poor and rich country trading partners rises with economic growth in the poor country. But individual commodity producers in rich countries can lose in this process, and they can be powerful advocates for restrictions on how development assistance is delivered to poor countries, if the result would be to jeopardize their market access. By thwarting public-sector support for agricultural development by the rich donors, these commodity interests are also thwarting more rapid economic growth and poverty reduction. 


\section{Stagnant technology and much more complicated problems}

Modern science and technology have wrought revolution after revolution in agriculture, resulting in crop yields and labor productivity so high in advanced countries that farmers are routinely paid to curb their abundance (Hayami and Ruttan, 1985; Johnson, 1997). The green revolution technologies that emerged from the CGIAR system in the 1960s provided a stimulus not just to the agricultural economies of the Asian countries able to utilize the fertilizer-responsive varieties of wheat and rice, but to pro-poor economic growth throughout the region.

But two problems loom increasingly large. First, cereal technologies for the most advanced agro-economic zones have been stagnant for a decade, and unless modern genetic technologies are brought to bear on the problem, there is little promise of a radical breakthrough in the visible future (Pingali, et al., 1997). This has caused DfID to raise the following questions:

Few doubt that achieving the MDG of halving the number of people living in absolute poverty by 2015 will require a significant improvement in agricultural performance, particularly in Africa. But in looking at the future and the likelihood of this being achieved, differences of opinion emerge around two key questions: ${ }^{5}$

1. Do the conditions exist for agricultural productivity to be increased where it is most needed and what part, if any, can small-scale agriculture play in achieving this?

2. Given quite fundamental differences in context between Asia in the Green Revolution and today's poorest countries, will the historical relationship between agricultural growth and poverty reduction continue to hold true?

Second, Africa's cropping systems and (lack of) water control make agricultural research complicated and expensive. There are few uniform tracts of mono-cropped cereals, with good water control and easy access to commercial inputs such as fertilizer, precisely the circumstances that made the green revolution feasible in Asia. The harsh environment, both agronomically and commercially, is one reason for the complex cropping systems and risk-averse behavior. But such cropping systems are notoriously hard to improve, because standard research methodologies seek to control all variables but the one under investigation. There are just too many variables for this approach to work very effectively in most African agricultural settings.

There have been successes (Wiggins, 2000). Hybrid maize and sorghum work well in Africa when appropriate inputs are available, and markets are available for the surpluses produced. High-value crops such as green beans and flowers are exported successfully to

\footnotetext{
${ }^{5}$ In comments on an earlier draft of this paper, Derek Byerlee took strong exception to the argument that technology for basic food grains has been stagnant for a decade, or that future productivity gains are highly questionable. But grain yields in Asia and Africa have been flat since the early 1990s (DfID, 2004, p. 8) and the highest yielding experimental varieties at IRRI are no more productive than a decade ago. Still, there are many opportunities for farmers to increase cereal yields through better management practices, even if the genetic potential of their seeds is not rising steadily.
} 
Europe. A number of tree crops thrive when infrastructure is available and border prices reach farmers. But the overall trend in food production per capita has been negative for two decades and there is little prospect of reversing that trend without massive investment in rural infrastructure and specialized agricultural research, neither of which seem to be on government or donor agendas. Adrian Wood, the Chief Economist for DfID, has painted a picture of an African continent "hollowed out," with most populations in the interior moving to the coasts, where they can be fed easily with imported food, and where access to ports and economies of scale in manufacturing might make the sector more competitive (Wood, 2002). That is not exactly a picture of propoor growth led by agriculture.

\section{Distracted donors and development faddism}

Development assistance is under challenge in most western societies. One set of critics argues that the funding levels are inadequate-Western European leaders are pushing for a doubling of official development assistance (ODA). In the United States, there is widespread doubt that development assistance works at all (Easterly, 2004). Analysts in the World Bank have been working hard to sort out what works and what does not. Their answer, perhaps not surprisingly, is that despite mistakes in the past, the donors in general and the World Bank in particular now know how to help poor countries get on a sustainable development path. More money, they argue, can be used very productively (Collier, 2002; Sachs, 2005). ${ }^{6}$

The goals and mechanisms of development assistance have broadened considerably since the field was founded in the 1950s. From an early emphasis on growth in gross domestic product (GDP) and containing communism, the mandate of most development agencies, and especially that of USAID, grew to include, among many other things, reductions in poverty, improvements in child health, gender equity, environmental sustainability, transition to market economies and democratization.

\footnotetext{
${ }^{6}$ The debate over the impact of foreign assistance has been played out recently in a series of econometric exercises that purport to show the impact, or lack thereof, of foreign assistance on economic growth in recipient countries. The current standard in this debate is Clemens, Radelet and Bhivnani (2004), who show that aid with expected impact in the "short-term," i.e. within the four-year horizon of their panel data, does indeed have a large, robust, and highly significant impact on economic growth. This short-term aid makes up about 45 percent of total aid, with another 45 percent devoted to "long-term" assistance, and 10 percent devoted to emergency and humanitarian assistance. Neither of the latter two components have a statistically significant impact on growth. Clemens, Radelet and Bhivnani also provide an extensive review of the theoretical and empirical literature leading up to their work.

${ }^{7}$ Many institutions involved in development activities saw similar broadening of agendas. The Development Advisory Service (DAS), founded by Harvard University in the early 1960s to help poor countries prepare economic development plans, expanded its scope in 1975 to become the Harvard Institute for International Development (HIID). New activities in health, education, and rural development were integrated into the Institute's traditional core of macroeconomists. The University's program on Women in Development was housed in HIID. An environmental program started in the late 1970s with the arrival of Theo Panayotou. Both in academia and government, development came to be seen as a multifaceted and complex process. This progress came at a cost, however. Focus was lost as agendas multiplied. Harvard closed HIID in 1999, arguing that it was managerially too complex for an academic institution.
} 
In the early 1990s, Brian Atwood tried to sharpen USAID’s increasingly blurred focus by withdrawing the Agency from its economic growth agenda and emphasizing several themes of great interest to Congress: short-run humanitarian assistance, especially food aid; health care, especially child survival and family planning programs; environmental sustainability, especially the development of agricultural technology for poor farmers, including women, working in fragile ecosystems; and gender issues more broadly. As the challenges and opportunities presented by the collapse of communism in the former Soviet Union became apparent, democratization was added as a USAID objective.

Somehow lost in the multiple agendas and donor efforts to program effectively in the face of developmental complexity was the need for poor countries to have growing economies as the only sustainable solution to all of their broader problems. To turn on its head the title of Paul Streeten's famous book on meeting basic needs, "first things first" means reestablishing economic growth as the foundation of development (Streeten, 1986). The review by the Economist (2004) of Sebastian Mallaby's recent book (2004) on James Wolfenson and the World Bank notes this lack of focus at the Bank and attributes it to too many "one issue" voices that Wolfenson, and the Bank, and the rest of the donor community, were listening to in an effort to be open and transparent to their critics. The Economist's criticism of Wolfenson is telling:

Trying to placate the Bank's critics seemed a good idea at the time, and he has managed to build constructive relationships with the more grown-up NGOs, such as OXFAM. Yet most pressure groups “do not have an off switch,” as Mr. Mallaby puts it. Nothing the Bank does will ever satisfy them, but by attaching some of the conditions that they demand to its loans, the World Bank makes those loans unattractive, despite their cheapness, to the more credit-worthy countries, such as Brazil, South Africa and China. ... Every infrastructure project the Bank funds must meet rich-world standards: nothing pretty may be bulldozed unless strictly necessary, and no worker may be asked to do anything that a Californian might find demeaning. As a result, fewer dams, roads and flood barriers are built in poor countries. More poor people stay poor, live in darkness and die younger (Economist, 2004, p. 99).

Partly because so many new topics are on the development agenda, and partly because there is no accepted core of development theory and only hotly contested empirical "truths," faddism has long dominated donor thinking about appropriate development strategy. From community development in the 1950s, to import substitution in the 1960s, to reaching the poorest of the poor in the 1970s, to structural adjustment in the $1980 \mathrm{~s}$, to sustainable development in the 1990s, and back to community development now (in the name of "community-driven development), the search for something "new" as the answer to poverty has actually impeded the implementation of core strategies that focus on sound governance, effective macro economic management, and a reliance on sustained public support for private markets.

From the point of view of enhancing pro-poor growth in developing countries - that is, linking the poor to rapid economic growth--leaders of donor agencies and managers of 
the global economy missed three opportunities over the past several decades. First, two decades intervened between the first and the second world food conferences with little to show in terms of increased food security and reduced poverty in the most vulnerable countries, those that might have hoped that Henry Kissinger's promise in 1976 that no child would go to bed hungry within a decade actually would translate into visible action (Timmer, 2005a).

Second, subsidies to farmers in rich countries remain extremely large, despite promises made at the Uruguay Round to reduce them significantly. The result has not just been a large budget burden in OECD countries. More importantly for developing countries, the result has been increasing surpluses dumped on world markets, depressing world prices and the incomes of farmers in poor countries who have to compete with these prices. The best guess is that every dollar of agricultural subsidies in rich countries costs farmers in poor countries a similar amount. Official development assistance is only one quarter of this total, and very little of it goes to rural economies. It is not a fair trade.

Third, the Cold War took a terrible toll on good governance. If we now recognize how important good economic governance is to the foundations of economic development, we are just coming to realize how the willingness of governments in the West to do business with any government ostensibly in the anti-communist camp undermined those institutional foundations. Many decades have been lost in the creation of sound economic governance and they cannot be recaptured overnight. Impatience on the part of donors will not help, and it may well impede progress.

\section{What Should Donors Do?}

It would be folly, or at least presumptuous, to offer detailed recommendations on what donors, and especially the World Bank, should do to revitalize the agricultural and rural economies of the poorest countries, and to hook these economies to a broader base of pro-poor growth. The "optimism" and "pessimism" camps identified in the DfID (2004) report have starkly different policy implications, for example. But there are six tasks that are pretty obvious, and need to be done whichever perspective is right, and it is appropriate to list them here. Developing them into country programs will be, well, country specific. But these tasks need to be done across the board.

\section{The obvious steps}

First, focus on the priority: economic growth that reaches the poor.

Second, invest in rural health and education, to enhance both productivity and mobility.

Third, make rural-to-urban migration easier when rural development is too expensive. 
Fourth, push hard on global trade reforms to make agriculture more profitable for developing countries. This will benefit both developed and developing countries.

Fifth, make major investments in agricultural science and technology at both the global and national levels. The historic rates of return on these investments have typically been three to four times the opportunity cost of capital. The failure to invest more is one of the great public failures of our time. Raising productivity of “orphan crops” may have especially high payoff for the poor.

Finally, develop local financing and planning mechanisms for investments in rural infrastructure. With political decentralization a reality in most developing countries, this is where the action will be in terms of investments that reach farm households.

\section{The "optimists" versus the "pessimists"}

Beyond these general recommendations, it seems likely that some countries probably offer hope along the "optimists" line of reasoning, and some fall into the "pessimists" camp. Again, which is which will be country-, or at least region-specific. But it is useful to summarize the conclusions that the DfID (2004) report offers in terms of policy approaches for each setting.

\section{Role for $\backslash$}

Rural human capital

Rural infrastructure

Agricultural research

Targeted safety nets

Input subsidies

Price guarantees/stability

\section{Optimists}

Yes, for productivity impact

Yes, for input and output markets

Yes, to raise yields and and lower food costs

A productive rural economy provides this

Needed to induce adoption of new technologies

Needed to maintain producer incentives and food security

\section{Pessimists}

Yes, for flexibility of exit

Mostly wasted

Private sector activity for specialized supply chains

Active government role to cushion transition to urban areas

Wasted

Difficult to implement within WTO rules 
These are very different views of the world. It seems unlikely that either the optimists or the pessimists are always right in all circumstances. But admitting that the pessimists are likely to be right some of the time in some countries places the onus on supporters of agricultural-led, pro-poor growth to show that it is feasible and efficient. History has been a powerful backer of this argument, but times have changed and the argument continues to need careful analytical and empirical support. 


\section{References}

Ashley, C., and Simon Maxwell. 2001. "Rethinking Rural Development.” Development Policy Review. Vol. 19, no. 4, pp. 395-425.

Ban, Sung Hwan, Pal Yong Moon and Dwight H. Perkins. 1980. Studies in the Modernization of the Republic of Korea: Rural Development. Published by the Council on East Asian Studies. Cambridge, MA: Harvard University Press.

Besley, Timothy, Robin Burgess and Berta Esteve-Volart. 2004. “Operationalizing Pro-Poor Growth: India Case Study.” Department of Economics, London School of Economics, (September), processed.

Bliss, C., and N. Stern. 1978. "Productivity, Wages and Nutrition: Parts I and II.” Journal of Development Economics. Vol. 5, no. 4, pp. 331-98.

Bonschab, Thomas, and Rainer Klump. 2004. “Operationalizing Pro-Poor Growth: Case Study Vietnam.” University of Frankfurt, (September), processed.

Brandt, Loren. "Interwar Japanese Agriculture: Revisionist Views on the Impact of the Colonial Rice Policy and the Labor-Surplus Hypothesis," Explorations in Economic History, Vol. 30 (1993), pp. 259-293.

Bravo-Ortega, Claudio, and Daniel Lederman. 2004. "Agriculture and National Welfare around the World: Causality and International Heterogeneity since 1960.” Draft paper for the Latin American and Caribbean Region Department of the World Bank. August 10, processed

Byerlee, Derek. 1973. “Indirect Employment and Income Distribution Effects of Agricultural Development Strategies: A Simulation Approach Applied to Nigeria.” African Rural Employment Paper, No. 9, Michigan State University, East Lansing, MI.

1999. "Targeting Poverty Alleviation in Priority Setting in National Research Organizations: Theory and Practice.” Plenary paper prepared for the CIAT international workshop, “Assessing the Impact of Research on Poverty Alleviation,” September 14-16, San Jose, Costa Rica.

Chenery, Hollis B., and Moshe Syrquin. 1975. Patterns of Development, 1950-1970. London: Oxford University Press.

Clemens, Michael, Steven Radelet, and Rikhil Bhavnani. "Counting Chickens When They Hatch: The Short-Term Effect of Aid on Growth,” Working Paper 44, Washington, D.C.: CGD, July 2004.

Collier, Paul. 2002. "Making Aid Smart: Institutional Incentives facing Donor Organizations and their Implications for Aid Effectiveness.” Forum Series on the Role of Institutions in Promoting Economic Growth. The IRIS Center, University of Maryland. February.

Cord, Louise. 2004. "Notes on the Country Studies." Project on Operationalizing Pro-Poor Growth, PREM/World Bank, Washington, DC. Processed.

Cummings, Ralph W., Jr., and Ashok Gulati. 2004. "Summary Report: Food Grain Marketing and the Role of Parastatals.” USAID/IFPRI Conference on Food Grain Markets in Asia, December, 2003, Delhi, India. Washington, DC. IFPRI.

Dasgupta, Partha. 1993. An Inquiry into Well-Being and Destitution. Oxford: Clarendon Press. 
Dawe, David. 2001. 'How far down the path to free trade? The importance of rice price stabilization in developing Asia’, Food Policy, 26(2):163-75.

2002. 'The changing structure of the world rice market, 1950-2000', Food Policy, 27(4):355-370.

Delgado, L. Chris, J. Hopkins, and V. A. Kelly. 1998. Agricultural Growth Linkages in Sub-Saharan Africa. IFPRI Research Report 107. Washington, DC: IFPRI.

Department for International Development (DfID). 2004. "Agriculture, Growth, and Poverty Reduction.” Prepared by the Agriculture and Natural Resources Team of the UK Department for International Development in collaboration with Anne Thomson of Oxford Policy Management, Oxford, (October).

Dollar, David, and Aart Kraay. 2002. "Growth is Good for the Poor.” Journal of Economic Growth. Vol. 7, pp.195-225.

Dorward, Andrew, Jonathan Kydd, Jamie Morrison, and Ian Urey. 2004. “A Policy Agenda for Pro-Poor Agricultural Growth.” World Development. Vol. 32, no. 1, pp. 73-89.

Dorward, Andrew, et al., eds. (2004), Institutions and Policies for Pro-Poor Agricultural Growth: Report on Project 7989, Department for International Development Social Science Research Unit, available at http://www.imperial.ac.uk/agriculturalsciences/research/sections/aebm/projects/poor_ag_downloa ds/finalrep.pdf

Easterly, William. 2004. “Can Aid Buy Development?” Address at the Center for Global Development, Washington, DC.

Economist. 2004. "James Wolfenson: Damned if you do." Review of The World's Banker: A Story of Failed States, Financial Crises, and the Wealth and Poverty of Nations, by Sebastian Mallaby.

Elliott, Kimberly. 2004. “Agricultural Protection in Rich Countries: How Did We Get Here?” CGD Commentary, June 27.

Fan, Shenggen, Peter Hazell and S. K. Thorat. 2000. "Government Spending, Agricultural Growth and Poverty in Rural India,” American Journal of Agricultural Economics, Vol. 82, No. 4, pp. 10381051.

Fan, Shenggen, L. Zhang and X. Zhang. 2002. Growth, Inequality and Poverty in Rural China: The Role of Public Investments. IFPRI Research Report 125, International Food Research Institute, Washington, DC.

Fan, Shenggen., S. K. Thorat, and Neetha Rao. 2004. Investment, Subsidies, and Pro-Poor Growth in Rural India, in Andrew Dorward, et al., eds. (2004), Institutions and Policies for Pro-Poor Agricultural Growth: Report on Project 7989, Department for International Development Social Science Research Unit.

Fogel, R.W. 1991. "The Conquest of High Mortality and Hunger in Europe and America: Timing and Mechanisms.” In P. Higonnet, D.S. Landes, and H. Rosovsky, eds., Favorites of Fortune: Technology, Growth, and Economic Development since the Industrial Revolution. Cambridge, MA: Harvard University Press, pp. 35-71.

Fogel, R.W. 1994. "Economic Growth, Population Theory, and Physiology: The Bearing of Long-Term Processes on the Making of Economic Policy.” [Nobel Prize Lecture] American Economic Review. Vol. 84, no. 3 (June), pp. 369-395. 
Food and Agriculture Organization of the United Nations (FAO). 2004. State of Food and Agriculture, 2003/4: Agricultural Biotechnology: Meeting the Needs of the Poor? Rome, Italy.

Fox, James W. 2002. "Development Overview.” Draft Chapter for "Natsios Report.” USAID, Washington, DC. January.

Gardner, Bruce L., 2002. American Agriculture in the Twentieth Century: How it Flourished and What it Cost. Harvard University Press, Cambridge, MA.

Haggblade, Steven, Jeffrey Hammer, and Peter Hazell. 1991. "Modelling Agricultural Growth Multipliers,” American Journal of Agricultural Economics, Vol. 73, No. 2, pp. 361-74.

Harvard Magazine. 2004. “John Harvard’s Journal: Re-Development,” Nov.-Dec. Vol. 107, page 57.

Hayami, Y., and V. Ruttan. 1985. Agricultural Development: An International Perspective. Revised and expanded edition. Baltimore: Johns Hopkins University Press.

Hayami, Yujiro and Toshihiko Kawagoe. 1993. The Agrarian Origins of Commerce and Industry: A Study of Peasant Marketing in Indonesia. London: St. Martin's Press.

Hazell, Peter, and Steven Haggblade. 1993. "Farm-Nonfarm Growth Linkages and the Welfare of the Poor.” In Michael Lipton and Jacques van der Gaag, eds., Including the Poor: Proceedings of a Symposium Organized by the World Bank and the International Food Policy Research Institute. The World Bank: Washington, DC.

Hazell, Peter, and Ailsa Roell. 1983. Rural Growth Linkages: Household Expenditure Patterns in Malaysia and Nigeria. IFPRI Research Report 41, Washington, DC.

Hu, Dinghuan, Thomas Reardon, Scott Rozelle, Peter Timmer and Honglin Wang. 2004. "The Emergence of Supermarkets with Chinese Characteristics: Challenges and Opportunities for China's Agricultural Development.” Development Policy Review, Vol. 22, no. 5, pp. 557-586.

Johnson, D.G. 1997. “Agriculture and the Wealth of Nations (Ely Lecture)," American Economic Review. Vol. 87, no. 2 (May), pp. 1-12.

Johnston, B.F., and J.W. Mellor. 1961. “The Role of Agriculture in Economic Development.” American Economic Review. Vol. 51, no. 4, pp. 566-93.

Johnston, Bruce F., and Peter Kilby. 1975. Agriculture and Structural Transformation: Economic Strategies in Late-Developing Countries. Oxford University Press.

King, Robert. P. and Derek Byerlee. 1978. "Factor Intensity and Locational Impacts of Rural Consumption Patterns in Sierra Leone.” American Journal of Agricultural Economics. Vol. 60, No. 2, pp. 197-206.

Kravis, Irving B. 1970. "Trade as a Handmaiden of Growth: Similarities between the Nineteenth and Twentieth Centuries.” The Economic Journal. Vol 80, no. 323, pp. 850-72.

Kuznets, S. 1955. "Economic Growth and Income Inequality.” American Economic Review. Vol. 49, no. 1, pp. 1-28.

Lanjouw, Jean and Peter Lanjouw. 2001. "The Rural Non-Farm Sector: Issues and Evidence from Developing Countries. Agricultural Economics. Vol. 26, No. 1, pp. 1-23. 
Larson, Don, and Yair Mundlak. 1997. “On the Intersectoral Migration of Agricultural Labor,” Economic Development and Cultural Change, pp. 295-319.

Lee, T. H. 1971. Intersectoral Capital Flows in the Economic Development of Taiwan, 1895-1960. Ithaca: Cornell University Press.

Lewis, W. Arthur. 1954. "Economic Development with Unlimited Supplies of Labor.” The Manchester School. Vol. 22, pp. 3-42.

Lipton, Michael. 1977. Why Poor People Stay Poor: Urban Bias in World Development. Cambridge, MA: Harvard University Press.

2004. Launching the DfID consultation "New Directions for Agriculture in Reducing Poverty.” Department for International Development. Available at http://dfid-agriculture-consultation.nri.org/launchpapers/simonmaxwell.html

Majid, Nooman. 2004. "Reaching Millennium Goals: How Well Does Agricultural Productivity Growth Reduce Poverty?” Employment Strategy Paper 2004/12, International Labor Organization (ILO), Geneva.

Mallaby, Sebastian. 2004. The World's Banker: A Story of Failed States, Financial Crises, and the Wealth and Poverty of Nations. The Penguin Press, NY.

Maxwell, Simon, 2004. 2004. "New Directions for Agriculture in Reducing Poverty: The DfID Initiative.” Department for International Development. Available at http://dfid-agriculture-consultation.nri.org/launchpapers/michaellipton.html

Mellor, John W. 1976. The New Economics of Growth: A Strategy for India and the Developing World. Ithaca, NY: Cornell University Press.

. 2000. "Agricultural Growth, Rural Employment, and Poverty Reduction: Non-Tradables, Public Expenditure, and Balanced Growth.” Prepared for the World Bank Rural Week 2000, March.

Mellor, John W., and Uma Lele. 1973. “Growth Linkages of the New Food Grain Technologies.” Indian Journal of Agricultural Economics. Vol. 18, No. 1, pp. 35-55.

Mellor, John W., and Bruce F. Johnston. 1984. "The World Food Equation: Interrelationships Among Development, Employment and Food Consumption.” Journal of Economic Literature. Vol. 22 (June), pp. 524-31.

Mew, T.W., D. S. Brar, S. Peng, D. Dawe, and B. Hardy. 2003. Rice Science: Innovations and Impact for Livelihood. Proceedings of the International Rice Research Conference, 16-19 September, 2002, Beijing, China. International Rice Research Institute, Chinese Academy of Engineering, and Chinese Academy of Agricultural Sciences. 1,022 pp.

Moon, Pal Yong. 1975. “The Evolution of Rice Policy in Korea.” Food Research Institute Studies, Vol. XIV, No. 4. pp. 381-402.

Morduch, Jonathan. 1999. “The Microfinance Promise,” Journal of Economic Literature. Vol. 37, no. 4, pp. 1569-1614.

Mosher, A.T. 1966. Getting Agriculture Moving: Essentials for Development and Modernization. New York: Praeger.

Mundlak, Yair. 2000. Agriculture and Economic Growth: Theory and Measurement. Cambridge, MA: Harvard University Press. 
Naylor, Rosamund, and Walter P. Falcon. 1995. "Is the Locus of Poverty Changing?” Food Policy, Vol 20, no. 6, pp. 501-518.

Naylor, Rosamund, Walter P. Falcon, et al., 2004. "Biotechnology in the Developing World: A Case for Increased Investment in Orphan Crops,” Food Policy, Vol. 29, pages 15-44.

Naylor, Rosamund, and Richard Manning. 2005. "Unleashing the Genius of the Genome to Feed the Developing World,” Proceedings of the American Philosophical Society.

Ohkawa, Kazushi. 1965. “Agriculture and Turning-Points in Economic Growth,” Developing Economies, Vol 3, no. 4.

Bruce F. Johnston and Hiromitsu Kaneda. 1969. Agriculture and Economic Growth: Japan's Experience. Tokyo: University of Tokyo Press.

and Henry Rosovsky. 1976. Japanese Economic Growth: Trend Acceleration in the Twentieth Century. Stanford: Stanford University Press.

Oshima, Harry. 1987. Economic Growth in Monsoon Asia: A Comparative Study. Tokyo: University of Tokyo Press.

OXFAM, 2002. "Boxing Match in Agricultural Trade: Will WTO Negotiations Knock out the World's Poorest Farmers?” OXFAM: Oxford, UK.

Pardey, Phillip, and N. Beintema. 2001. "Slow Magic: Agricultural R\&D a Century after Mendel.” Agricultural Science and Technology Indicators. Washington, DC: IFPRI. Available at http://www.ifpri.org/pubs/fpr31.pdf

Pingali, Prabhu L., Mahabub Hossain and Roberta V. Gerpacio. 1997. Asian Rice Bowls: The Returning Crisis? CABI Publishing, International Rice Research Institute, Los Banos, the Philippines.

Prasada Rao, D.S., Angus Maddison and Boon Lee. 2002. "International Comparison of Farm Sector Performance: Methodological Options and Empirical Findings for Asia-Pacific Economies, 190094." n Angus Maddison, D.S. Prasada Rao and William F. Shepherd, eds, The Asian Economies in the Twentieth Century. Edward Elgar. pp. 27-52.

Ranis, Gustav, and Frances Stewart. 1987. "Rural Linkages in the Philippines and Taiwan.” In Frances Stewart, ed., Macro-Policies for Appropriate Technology in Developing Countries. Boulder, Colorado: Westview Press.

Ravallion, Martin, and Shaohua. Chen. 2004. "China’s (Uneven) Progress Against Poverty.” Development Research Group, World Bank, Washington, DC., August, Processed

Ravallion, Martin., and G. Datt. 1996. "How Important to India's Poor Is the Sectoral Composition of Economic Growth?” The World Bank Economic Review. Vol. 10, no. 1, pp. 1-25.

Ravallion, Martin, and Monika Huppi. 1991. "Measuring Changes in Poverty: A Methodological Case Study of Indonesia during an Adjustment Period.” World Bank Economic Review. Vol. 5, no. 1, pp. 57-82.

Reardon, T., C. P. Timmer, C. B. Barrett, and J. A. Berdegue. 2003. "The Rise of Supermarkets in Africa, Asia, and Latin America.” American Journal of Agricultural Economics, Vol. 85, No. 5, pp. 1140-46. 
Reardon, Thomas, and C. Peter Timmer. Forthcoming. "Transformation of Markets for Agricultural Output in Developing Countries Since 1950: How Has Thinking Changed?” Chapter 13 in Robert Evenson, Prabhu Pingali and T. Paul Schultz, eds., Handbook of Agricultural Economics, Vol. 3A, Amsterdam: North-Holland.

Sachs, Jeffrey D. 2005. The End of Poverty: Economic Possibilities for our Times. New York: The Penquin Press

Sarris, Alexander H. 2001. "The Role of Agriculture in Economic Development and Poverty Reduction: An Empirical and Conceptual Foundation.” Prepared for the Rural Development Department of the World Bank, Washington, DC. March.

Schultz, T. Paul. 1993. "Sources of Fertility Decline in Modern Economic Growth: Is Aggregate Evidence on the Demographic Transition Credible?” New Haven, CN: Economics Department, Yale University; typescript.

Schultz, T.W. 1964. Transforming Traditional Agriculture. New Haven: Yale University Press. ., ed. 1978. Distortions of Agricultural Incentives. Bloomington: Indiana University Press.

Sen, Binayak, Mustafa K. Mujeri and Quazi Shahabuddin. 2004. “Operationalizing Pro-Poor Growth: Bangladesh as a Case Study.” BIDS, Dhaka/IDPM, (November 7), processed.

Smith, L. E. D., and I. Urey. 2002. "Agricultural Growth and Poverty Reduction: A Review of Lessons from the Post-Independence and Green Revolution Experience in India.” Research project on Institutions and Economic Policies for Pro-Poor Agricultural Growth, funded by the Department for International Development (DfID) of the United Kingdom. Department of Agricultural Sciences, Imperial College at Wye, (October), processed.

Strauss, J. 1986. “Does Better Nutrition Raise Farm Productivity?” Journal of Political Economy. Vol. 94, no. 2, pp. 297-320.

Strauss, J., and D. Thomas. 1998. "Health, Nutrition, and Economic Development." Journal of Economic Literature. Vol. XXXVI, no. 2 (June), pp. 766-816.

Streeten, Paul. 1986. First Things First: Meeting Basic Human Needs. Baltimore, MD: Johns Hopkins University Press for the World Bank.

Sumarto, Sudarno, and Asep Suryhadi. 2003. "The Indonesian Experience on Trade Reform, Economic Growth and Poverty Reduction,” Presented at the Trade, Growth and Poverty Conference, December 8-9, London. The SMERU Research Institute, Jakarta, processed.

Tabor, Steven R. 2002 "Indonesian Rice Policy and the Choice of Trade Regimes.” Prepared for the BULOG seminar on alternative options for rice trade policy. Jakarta, Indonesia. March.

Thirtle, Colin, Lin Lin, and Jenifer Piesse. 2003. "The Impact of Research-Led Agricultural Productivity Growth on Poverty Reduction in Africa, Asia and Latin America,” World Development, Vo. 31, No. 12, pp. 1959-1975.

Tiffin, Richard. 2004. “Is Agriculture the Engine of Growth?” Working Paper, University of Reading, (March 10), pp. 1-21.

Timmer, C. P. 1969. "The Turnip, the New Husbandry, and the English Agricultural Revolution," Quarterly Journal of Economics, vol. 83, no. 3 (August), pp. 375-395. 
. 1988. “The Agricultural Transformation.” In H. Chenery and T.N. Srinivasan, eds., Handbook of Development Economics. Vol. 1. Amsterdam: North-Holland, pp. 275-331.

. 1991. "Food Price Stabilization: Rationale, Design, and Implementation," in Dwight H. Perkins and Michael Roemer, eds., Reforming Economic Systems. Cambridge: Harvard Institute for International Development, Harvard University. Distributed by Harvard University Press, pp. 219-48 and pp. 456-59.

. 1993. "Rural Bias in the East and Southeast Asian Rice Economy: Indonesia in Comparative Perspective.” In A. Varshney, ed., Beyond Urban Bias. London: Frank Cass, pp. 149-76.

1995. “Getting Agriculture Moving: Do Markets Provide the Right Signals?” Food Policy, Vol. 20, no. 5, pp. 455-72.

1996. "Economic Growth and Poverty Alleviation in Indonesia.” Research in Domestic and International Agribusiness Management, Volume 12. JAI Press.

1997. “How Well do the Poor Connect to the Growth Process?” Harvard Institute for International Development for the USAID/CAER project, December, processed.

. 2002. “Agriculture and Economic Growth.” In Bruce Gardner and Gordon Rausser, eds., Handbook of Agricultural Economics, Vol. IIA. Amsterdam: North-Holland. . 1487-1546.

. 2003. "Biotechnology and Food Systems in Developing Countries.” Journal of Nutrition, Vol. 133, No. 11 (November), pp. 3319-22.

. 2004a. “The Road to Pro-Poor Growth: Indonesia’s Experience in Regional Perspective.” Bulletin of Indonesian Economic Studies, Vol. 40, no. 2 (August), pp. 177-207.

. 2004b. "Food Policy in the Era of Supermarkets: What's Different? Journal of Agricultural and Development Economics (electronic), Vol. 1, no. 2, pp. 50-67. Available at http://www.fao.org/es/esa/eJADE

. 2005a. "Food Security and Economic Growth: an Asian Perspective." H. W. Arndt Memorial Lecture, Australian National University, Canberra (November 22), in Asian-Pacific Economic Literature. Vol. 19, pp. 1-17.

2005b. "Operationalizing Pro-Poor Growth: Country Case Study on Indonesia for the World Bank.” Center for Global Development, (June 6), processed, pp. 104.

2005c. "Raising Rural Productivity in Indonesia: A Conceptual and Regional Perspective on Policy Approaches.” Draft manuscript for the World Bank and the Center for Global Development (July), processed, pp. 52.

Timmer, C. Peter and David Dawe. 2005. "Managing Food Price Instability in Asia: A Macro Food Security Perspective,” Manuscript prepared for the World Bank, Washington, DC. Processed.

Timmer, C. Peter and Neil McCulloch. 2005. “Are Indonesian Rural Non-Farm Enterprises still 'In the Shadow of Agriculture?’ A Framework for Analysis of the Pathways out of Rural Poverty.” Manuscript. World Bank, Jakarta, processed.

van der Eng, Pierre. "Agricultural Development in Indonesia and Japan," (Chapter 5) in Agricultural Growth in Indonesia since 1880: Productivity Change and the Impact of Government Policy. Groningen, Netherlands: Rijksuniversiteit Groningen, 1993, pp. 224-249. 
Warr, Peter G. 2003. “Industrialisation, Trade Policy and Poverty Reduction: Evidence from Asia.” Paper for a Festschrift in honor of Professor Peter Lloyd, University of Melbourne, 23-24 January, processed.

Westphal, Larry, and Sherman Robinson. 2002. The State of Industrial Competitiveness in Developing Countries. UNDP, New York.

Wiggins, S. 2002. "Interpreting Changes from the 1970s to the 1990s in African Agriculture through Village Studies.” World Development. Vol. 28, No. 4, pp. 631-662.

Wood, Adrian. 2002. “Could Africa Be Like America?.” Address to the Advisory Board of the Research Program on Enterprise Development (RPED), World Bank.

World Bank. 2004a. “Operationalizing Pro-Poor Growth.” A Research Project Sponsored by AFD, DFID, GTZ, KfW and PREM. Washington, DC.

World Bank. 2004b. “India: Re-energizing the Agricultural Sector to Sustain Growth and Reduce Poverty.” Review Team led by Dina Umali-Deininger, (April), processed.

. 2004c. "Promoting the Rural Non-Farm Sector in Bangladesh.” Rural Development Unit,

South Asia Region, Team led by Forhad Shilpi, (August), processed in two volumes.

2004d. Directions in Development: Agriculture and Poverty Reduction. Agriculture and

Rural Development Department. September.

Zeller, M., and Richard I. Meyer, eds., 2002. The Triangle of Microfinance: Financial Sustainability, Outreach and Impact. Johns Hopkins University Press for the International Food Policy Research Institute (IFPRI): Baltimore. 